\title{
Recreational fisheries pressure in the Polish waters of the Vistula Lagoon and considerations of its potential impact on the development of regional tourism
}

\author{
Marek Trella, Maciej Mickiewicz
}

Received - 17 October 2016/Accepted - 22 December 2016. Published online: 31 December 2016; $\odot$ Inland Fisheries Institute in Olsztyn, Poland Citation: Trella M., Mickiewicz M. 2016 - Recreational fisheries pressure in the Polish waters of the Vistula Lagoon and considerations of its potential impact on the development of regional tourism - Arch. Pol. Fish. 24: 231-242.

\begin{abstract}
The aim of this paper is to present the recreational fisheries on the Vistula Lagoon and their potential impact on the development of regional tourism. Questionnaires were used to collect information during investigations conducted in the 2012-2015 period. Additional information on the topic of angling tourism was obtained by conducting interviews with recreational fishers and with the owners of angling shops. The numbers of angling permits issued was also analyzed. This analysis indicated growing interest in recreational fisheries in the Vistula Lagoon, where anglers caught primarily perch, Perca fluviatilis L., and pikeperch, Sander lucioperca (L). The recreational fishers surveyed resided mainly in areas near the Vistula Lagoon. The mean distance between their homes and the fishing grounds was $30.5 \mathrm{~km}$ (min-max: 0.1-757 km). SWOT analysis indicated that recreational fisheries in the Vistula Lagoon could be a stimulatory factor for the development of tourism in the region.
\end{abstract}

Keywords: Baltic coastal lagoon, recreational fishing, angling survey, fishing tourism

M. Trella [ $\left.\Xi^{\circ}\right]$, M. Mickiewicz

Department of Fisheries Bioeconomics

Inland Fisheries Institute in Olsztyn

ul. Oczapowskiego 10, 10-719 Olsztyn, Poland

e-mail: m.trella@infish.com.pl; tel. +48 895241042

\section{Introduction}

Modern day recreational fishery escapes a simple definition (Szczerbowski 1998, Arlinghaus and Cook 2009) that could fully describes its significance. From the viewpoint of the average angler, recreational fishing meets several different basic needs, including recreation (it is one form of spending time in the outdoors), consumption (it is one way to obtain healthy food), and sport (it can be competitive). Recreational fishing tourism strives to satisfy all of these needs (Wołos 2006).

In Poland, angling is frequently mentioned as one of the attractions offered by tourist or vacation facilities located near lakes, rivers, the sea, and lagoons, but it is most often listed among other attractions. In Poland, approximately 1.5 million people are relatively active anglers (Wołos 2006). Despite this, recreational fishing tourism does not function independently on a macro-scale, as it does, for example, in Scandinavian countries (Borch 2004). On the micro-scale of individual tourist facilities, the variety of services offered to recreational fishers has increased. After the political and economic changes (Mickiewicz 2013), the fisheries sector became more interested in the needs of anglers, and not just in selling recreational fishing permits,

\footnotetext{
(c) Copyright by Stanisław Sakowicz Inland Fisheries Institute in Olsztyn.

(c) 2016 Author(s). This is an open access article licensed under the Creative Commons Attribution-NonCommercial-NoDerivs License (http://creativecommons.org/licenses/by-nc-nd/3.0/).
} 
but also in stocking fish species of interest to these fishers and in creating special fishing grounds (Wołos 2000). Angling combined with vacationing in the great outdoors is a specific type of tourism, which, including recreational fishing tourism, is or can become an important developmental element in many regions (Czarkowski et al. 2012a).

The Vistula Lagoon is an internal aquatic basin located on the southeastern coast of the Baltic Sea. The surface area of the lagoon is $838 \mathrm{~km}^{2}$, of which $328 \mathrm{~km}^{2}$ lies within the borders of Poland, while the rest of it lies on the Russian side of the border where it is known as the Kaliningrad Lagoon (Kruk 2011, Trella 2014). The lagoon is classified as brackish with a salinity that usually does not exceed $4 \%$ in the Polish part; elevated salinity levels are caused by inflows of saline marine waters. The largest rivers that currently flow into the lagoon are the Pregoła and Pasłęka, while, until 1914, some of the waters from the Vistula River also flowed into it (Miotk-Szpiganowicz et al. 2007, Kruk 2011, Trella 2014). The most abundant fish species in the lagoon are cyprinids and percids with seasonal occurrences of herring, Clupea harengus L., and European smelt, Osmerus eperlanus (L). Formerly, eel, Anguilla anguilla (L.), also occurred here abundantly. The fairly stable population of sichel, Pelecus cultratus (L.), is noteworthy. The ichthyofauna is not homogeneous throughout the lagoon, because it varies depending on salinity and trophic conditions, which is why cyprinids dominate in the southwest and the share of percids is larger in the east (Psuty-Lipska and Borowski 2003, Psuty 2009, Trella 2014). Tourism is noteworthy in the vicinity of the lagoon with its many operational ports and fishing bases. Plans in the nearest future include developing and revitalizing existing ports, among other investments. The sightseeing and natural aspects of the areas surrounding the lagoon are also highly valued (Trella 2014).

The Vistula Lagoon is an example of one such region since it is a basin that is of great interest to recreational fishers. Studies to date have shown that the Vistula Lagoon is thought of as a good recreational fishing ground (Trella 2014, 2015). The low fees for fishing permits, both short term and annual, relatively low fishing pressure, the large size of the basin, and the many attractive species that inhabit it all contribute to its popularity among anglers (Trella 2014).

Studies of recreational fishing tourism have been conducted for many years. These confirm that marine angling can stimulate the development of regional tourism (Marciniak and Kałuża 2010, Moksness et al. 2011), while lake angling is one element of lake tourism (Kurleto 2013). These studies also indicate that recreational fisheries have a substantial impact on the overall development of tourism in coastal and lake regions. In addition to the positive impact recreational fisheries have in stimulating the development of local tourism, threats have also been identified in conjunction with them, including the overfishing of some fish species (Cooke et al. 2014) and environmental degradation (Cooke and Cowx 2006).

The aim of the current study is to present the recreational fisheries on the Vistula Lagoon in light of their potential impact on the development of tourism in this region. SWOT analysis is presented in order to determine the development strategy of the region with a particular focus on recreational fisheries.

\section{Materials and methods}

The analysis of recreational fisheries in the Vistula Lagoon was performed based on anonymous questionnaires distributed and collected in the 2012-2015 period and which referred to recreational fishing in the 2011-2014 period. Questionnaire studies were conducted in towns located on the Vistula Lagoon, i.e., Frombork, Braniewo, Tolkmicko, Nowa Pasłęka, Różaniec, Sztutowo, and Kąty Rybackie (Fig. 1). A total of 401 questionnaires were collected.

The questionnaire concerning recreational fisheries in lagoon waters was prepared based on previous questionnaire studies on recreational fisheries in Polish inland waters (Bnińska and Wołos 2001, Wołos et al. 2015). Data gathered in the 


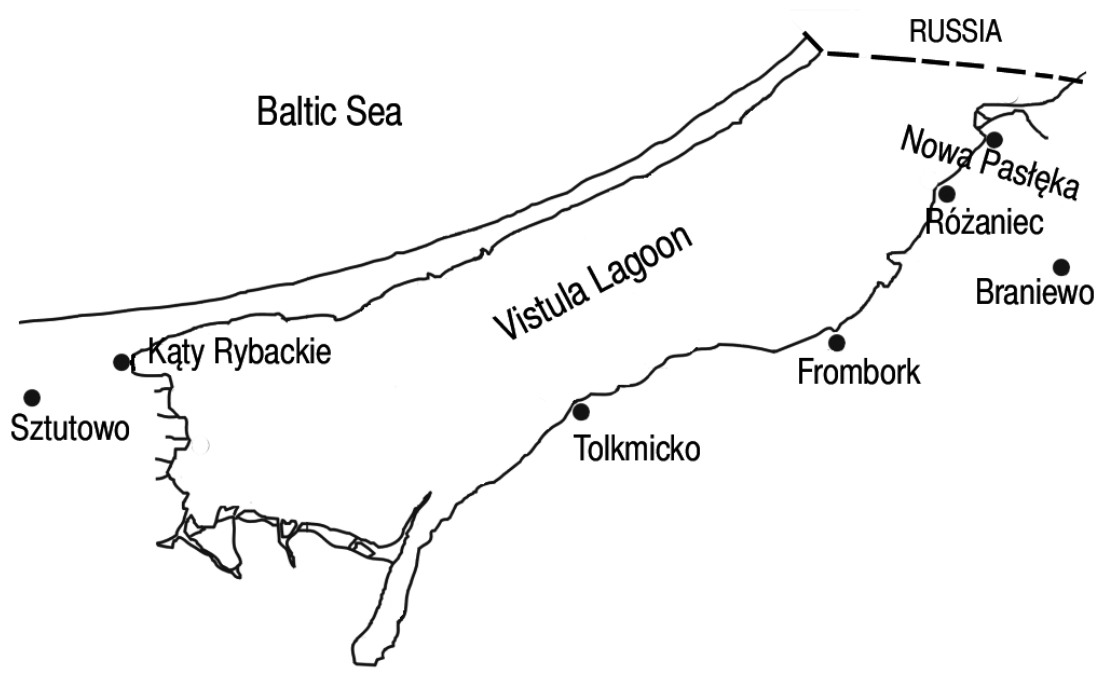

Figure 1. Map of the Vistula Lagoon showing the study areas and localities mentioned in the text.

2011-2012 period were used in a preliminary analysis of recreational fisheries in lagoon waters (Trella 2014, 2015). Together with data from the 2013-2014 period, they permitted analyzing the following: fishing location, number of fishing days, number of fishing hours, distance between place of residence and the fishing grounds.

The species structure of fish caught in the lagoon in the 2011-2014 period by recreational fishers was determined by analyzing the questionnaires. The mean biomass of fish caught per angler was also determined. This data was used to estimate the mean fish biomass caught in the 2011-2014 period by all anglers who purchased fishing permits. The total fish biomass caught by anglers in the Vistula Lagoon was estimated based on the mean biomass of fish caught per angler $(n=401)$ and all of the permits issued by the District Inspectorates of Marine Fisheries (DIMF). It was assumed that $5 \%$ of recreational fishers who obtained fishing permits from the DIMF did not fish in the lagoon, but in other Polish marine waters (Trella 2014). These data were compared to commercial catches from 2014 (Szostak et al. 2015). Comparisons were also made with the $\mathrm{Chi}^{2}$ test.

In this study, the measure of recreational fishing pressure is the number of recreational fishing permits sold. The number of recreational fishing permits was analyzed using sales records from the DIMF
Frombork and DIMF Sztutowo in the 2000-2014 period. The dynamics of recreational fishing permit sales in the 2000-2014 period were described using time series analysis assuming a degree of probability of $\mathrm{p} \leq 0.05$. Recreational fishing permit sales were compared to their use by recreational fishers throughout the year with the $\mathrm{Chi}^{2}$ test. All calculations and figures were made with Microsoft Excel.

The basic techniques of the method were applied in the SWOT analysis (Cholewicka-Goździk 2009). They are to sort information, in this case interviews with anglers and angling shop owners and our own observations on the topic of recreational fisheries in the Vistula Lagoon, into four groups of strategic factors: $\mathrm{S}$ - strengths included everything that is an asset, an advantage, a positive point related to recreational fisheries and recreational fishing tourism in the Vistula Lagoon region; W weaknesses included everything that is a disadvantage, a barrier, or a drawback with regard to recreational fisheries and recreational fishing tourism in the Vistula Lagoon region; $\mathrm{O}$ - opportunities included everything that provides recreational fishing and tourism in the Vistula Lagoon region with a chance for positive change; $\mathrm{T}$ - threats included everything that poses a danger of causing disadvantageous changes to recreational fishing and/or tourism in the Vistula Lagoon region. 


\section{Results}

\section{Analysis of recreational fisheries pressure}

A significant increase in the sale of recreational fishing permits was noted in the $2000-2014$ period ( $\mathrm{P}<$ 0.05; Fig. 2). In 2014, nearly nine times more recreational fishing permits were issued than in 2000. The trend observed in 2000-2014 was stable despite slight decreases in the numbers of permits sold in 2002, 2008, and 2010.
The distribution of the recreational fishing permits sold by the DIMF in the 2011-2014 period in both DIMF offices in Frombork and Sztutowo was the same as that determined based on the questionnaire data (test $\mathrm{Chi}^{2}, \mathrm{P}<0.05$; Fig. 3). Anglers usually chose to take their vacations in spring and summer, which is when they purchase their recreational fishing permits. The peak of recreational fishing permit sales was during the May to July period, and the most fishing days were noted from June to August.

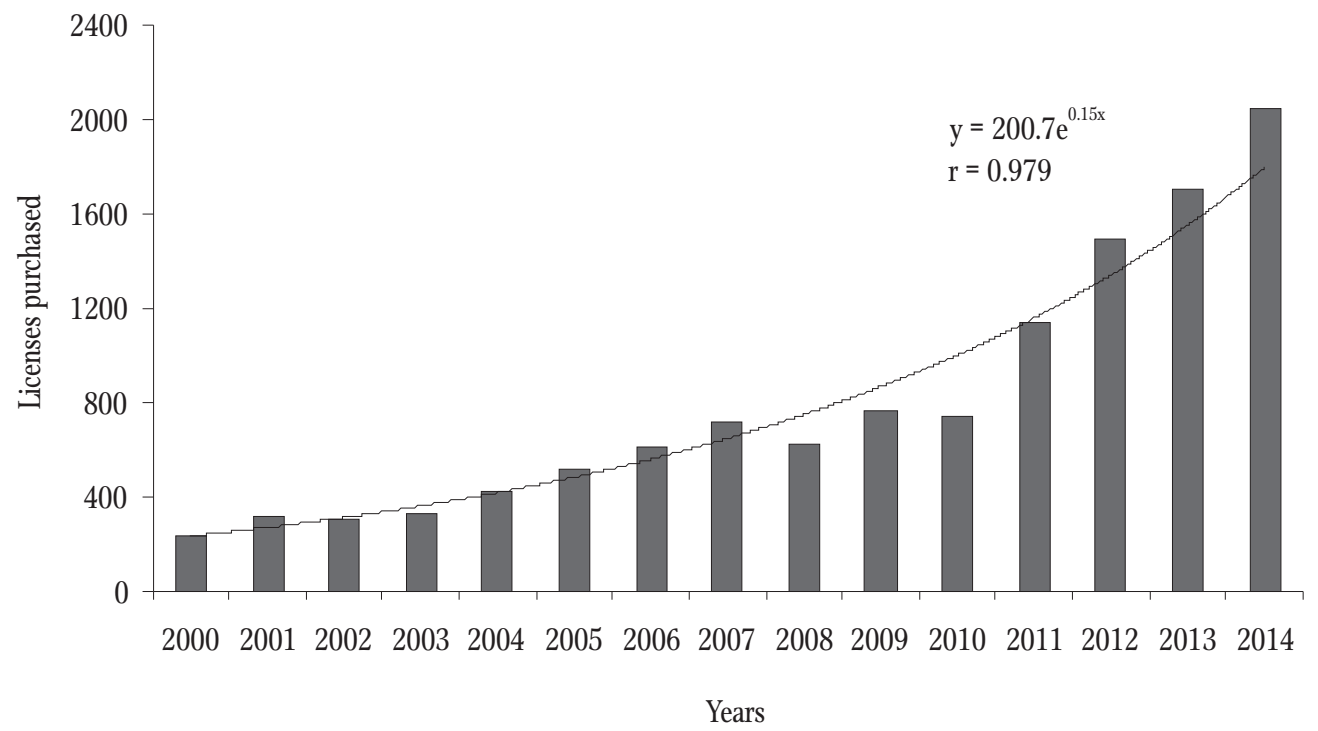

Figure 2. Dynamics of recreational fishing permit sales by the District Inspectorates of Marine Fisheries in Sztutowo and Frombork in 2000-2014.

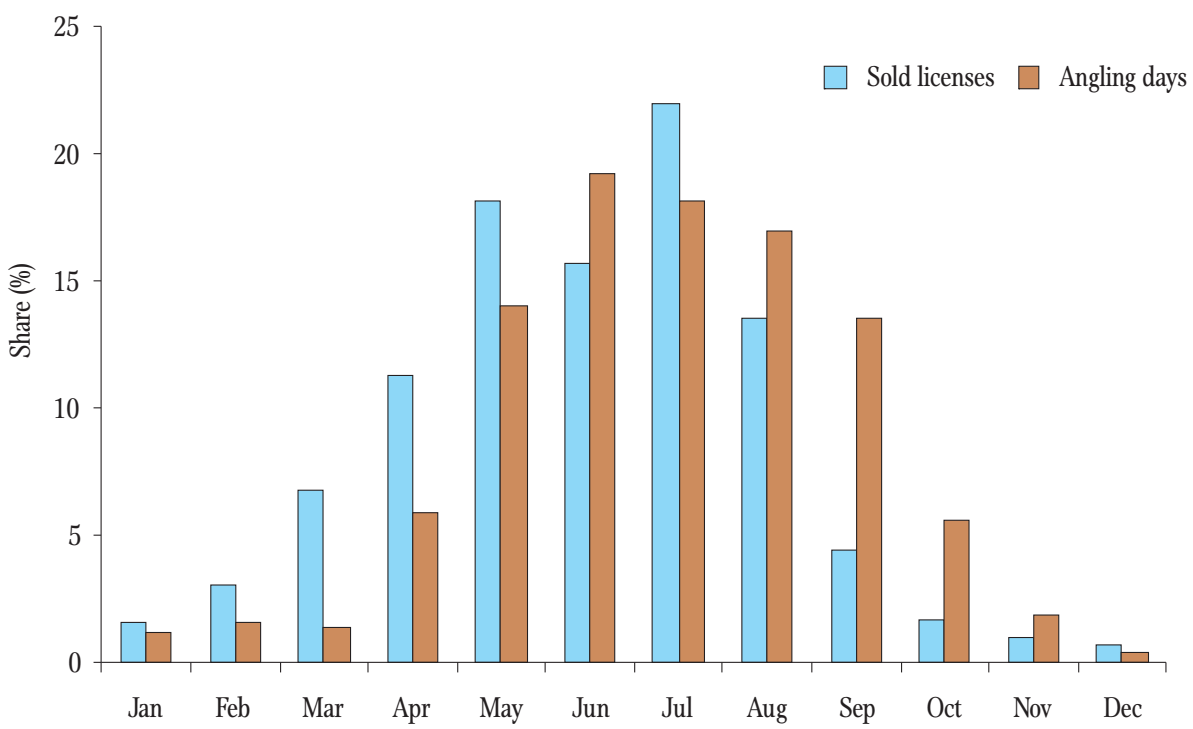

Figure 3. Relative frequencies of the angling hours per day in the Vistula Lagoon in 2011-2014. 

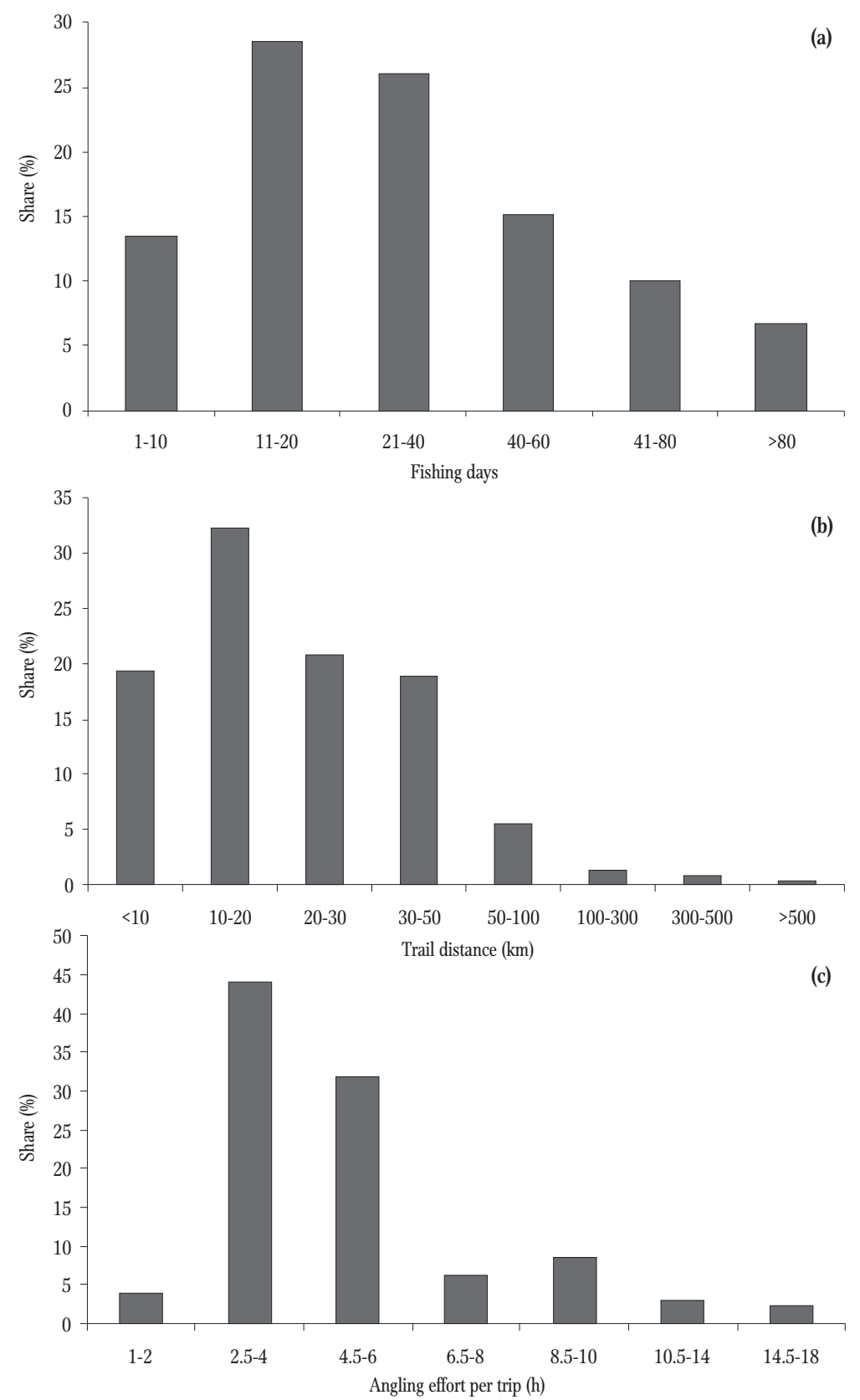

Figure 4. Fishing effort of the recreational fishers in the Vistula Lagoon according to the interviews conducted in 2011-2014: (a) number of trips per angler and year, (b) travel distance, (c) angling hours per day.

Most of the anglers fishing the Vistula Lagoon in the 2011-2014 period declared that they did so from the shore $(50.4 \%)$. More than $25 \%$ of them fished from the shore and from boats, while the fewest recreational fishers declared that they only fished from boats (21.5\%). The mean number of fishing days per angler in the 2011-2014 was 31.5 days within a range of 1 to 152 days (Fig. 4a). The anglers' permanent residence was an average of $30.5 \mathrm{~km}$ from the Vistula Lagoon. The analysis of the distance between anglers' permanent place of residence and the lagoon indicates that most of the recreational fishers were local residents, although there were even some anglers from abroad (Fig. 4b). The average fishing time per angler was 5.2 hours daily, while range of time spent fishing was from 1 to 18 hours (Fig. 4c). 


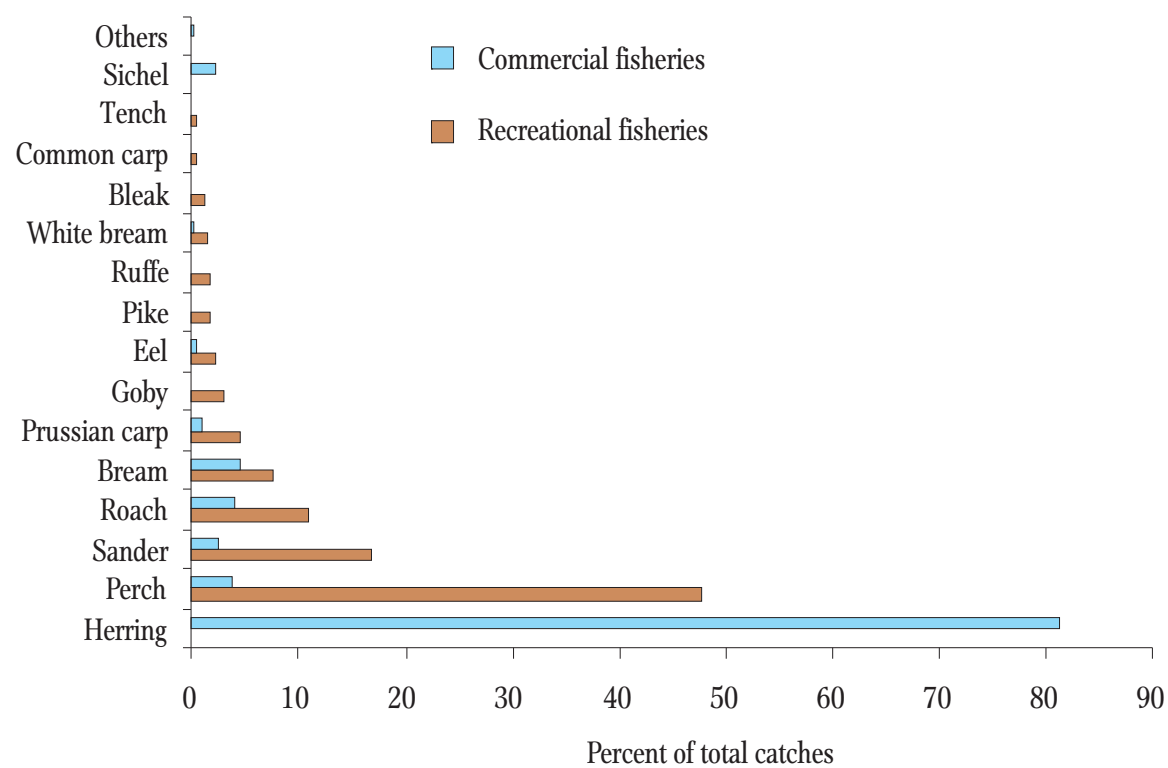

Figure 5. Comparison of the species structure of fish caught in the Vistula Lagoon by recreational and commercial fishers. Commercial catches according to Szostak et al. (2015).

\section{Species structure and size of recreational}

\section{fisheries}

Recreational fishers caught from 0.5 to $376 \mathrm{~kg}$ of fish annually in the Vistula Lagoon. The mean annual catch of fish per angler was $38.8 \mathrm{~kg}$. In the period studied from 2011 to 2014, recreational fishers caught an annual mean of 58.9 tons of fish at a range of 39.6 to 74.5 tons. Twenty-one fish species were noted in the recreational fishing questionnaires. Perch, Perca fluviatilis L., and pikeperch, Sander lucioperca (L.) comprised the largest part of the recreational catches (Fig. 5), and these two species contributed close to $65 \%$ of the biomass of the fish caught. Catches of bream, Abramis brama (L.), and roach, Rutilus rutilus (L.), fluctuated at 10.9 tons, while their combined contribution was $18.5 \%$. The combined share of crucian carp, Carassius carassius (L.), and Prussian carp, Carassius gibelio (Bloch), was $4.4 \%$. Goby is a term used to refer to all the Gobiidae fishes caught in the Vistula Lagoon in the 2011-2014 period, because fishers do not distinguish among the various species. Based in the interviews conducted, the round goby, Neogobius melanostomus (Pall.), was the most frequently caught species. The nearly 3-ton catches of it reported could be underestimated since many anglers, despite catching it, do not consider it worthwhile to mention it in questionnaires. Not until they were interviewed did they mention that they had caught gobies and sometimes even in large quantities. The remaining species represent a smaller percent share of the catches. Commercial fishing in the Vistula Lagoon targets other fish species (test $\mathrm{Chi}^{2}, \mathrm{P}<0.05$; Fig. 5). Comparing recreational and commercial fisheries catches indicates there is significant pressure on herring, Clupea harengus L. The other species, mainly cyprinids, represent a small percent of commercial catches.

\section{SWOT analysis}

The SWOT analysis presents a comprehensive analysis of the recreational fisheries in the Vistula Lagoon in terms of their potential impact on the development of tourism in the region (Table 1). This analysis takes into consideration both internal and external factors that could have a definitive impact on the development strategy of this fishing ground. The strengths include recreational fishing advantages and the tourist attractions of the Vistula Lagoon vicinity. The weaknesses include the poor road, tourism, and 
Table 1

SWOT analysis of recreational fisheries in the Vistula Lagoon

\begin{tabular}{|c|c|}
\hline Strengths & Weaknesses \\
\hline $\begin{array}{l}\text { 1. Relatively low fees for weekly, monthly or annual permits. } \\
\text { 2. Relatively low recreational fisheries pressure. } \\
\text { 3. Abundantly occurring and diverse fish species that are attractive to } \\
\text { anglers. }\end{array}$ & $\begin{array}{l}\text { 1. Road infrastructure of the area surrounding the Vistula Lagoon. } \\
\text { 2. Lagoon shores are difficult to access. } \\
\text { 3. Lack of accommodation. }\end{array}$ \\
\hline $\begin{array}{l}\text { 4. Tourist attractions and scenic areas surrounding the Vistula } \\
\text { Lagoon. }\end{array}$ & 4. Few angling shops. \\
\hline $\begin{array}{l}\text { 5. Large number of available ports and fishing bases. } \\
6 \text {. Numerous functioning waterways. }\end{array}$ & $\begin{array}{l}\text { 5. Few angling guides. } \\
\text { 6. Few places to rent aquatic equipment. }\end{array}$ \\
\hline Opportunities & Threats \\
\hline $\begin{array}{l}\text { 1. Create comprehensive tourism infrastructure based on the } \\
\text { popularity of the Vistula Lagoon as a recreational fishing ground. }\end{array}$ & 1. Increased angling permit fees. \\
\hline $\begin{array}{l}\text { 2. Expanding recreational fisheries infrastructure - angling shops, } \\
\text { angling guides, boat rental, etc. }\end{array}$ & $\begin{array}{l}\text { 2. Overfishing from excessive pressure from recreational and } \\
\text { commercial fisheries. }\end{array}$ \\
\hline 3. Increasing interest in tourism in the vicinity of the Vistula Lagoon. & 3. Conflicts between recreational and commercial fishers. \\
\hline 4. Influx of investors and capital. & $\begin{array}{l}\text { 4. Growing cormorant population destroying fish fauna in the Vistula } \\
\text { Lagoon. }\end{array}$ \\
\hline 5. Local community integration. & 5. No subsidies for recreational fishing tourism development. \\
\hline $\begin{array}{l}\text { 6. Growing trend in recreational fisheries of choosing to fish marine } \\
\text { waters, including the waters of coastal lagoons. }\end{array}$ & $\begin{array}{l}\text { 6. Lack of support from state institutions and the private sector for } \\
\text { measures to increase tourism. }\end{array}$ \\
\hline
\end{tabular}

recreational fisheries infrastructure. Opportunities include all potential pro-development assets. The main threats include potential economic, ecological and social problems.

\section{Discussion}

The data presented in this article were drawn from anonymous recreational fisheries questionnaires. In Poland, this method of data collection is used widely in studies of inland recreational fisheries (Wołos 2006). Data concerning marine recreational fisheries come from logs kept in fishing ports or during marine cruises (Marciniak and Kałuża 2010, Radtke and Dąbrowski 2015). For recreational fisheries from coastal areas, it is common worldwide to use questionnaires to collect wide-ranging information regarding recreational fishers, including their gender, age, income, fish species preferences, and how they engage in recreational fisheries (level of recreational catches, species composition of caught fish, length of fishing) (Joyeux and Ward 1998, Montano et al. 2005, Veiga et al. 2010).

The observed increase in interest from recreational fishers in the fishing ground provided the impetus for undertaking socioeconomic studies to describe this group which exploits these waters. The Vistula Lagoon was long a fishing ground that was not well known or popular among anglers. The first information concerning recreational fisheries in the Vistula Lagoon was published in 2003 in the monthly magazine Wędkarz Polski (Polish Angler) (Dębicki 2003). The first scientific report focusing on the issue of recreational fisheries in the Vistula Lagoon was published in 2013, and it signaled undertaking comprehensive studies on recreational fisheries pressure and catches in the Vistula Lagoon (Trella 2013). Trella published the first scientific analysis on this topic in 2014. Anglers usually report that predatory fish are the most desirable species to catch (Wołos 1992, 1994, Wołos et al. 2015). In addition to these, they also caught other species in the 
Vistula Lagoon that are considered to be attractive such as crucian carp and common carp. It is noteworthy that information regarding the most frequently caught fish in actual recreational catches is reflected in the declared preferences of recreational fishers (Trella 2014).

The recent growing interest of anglers in the Vistula Lagoon stems from several factors. One of the most important is permit fees, which, until 2015, were low at a maximum of 49 PLN (approximately 11 euros) for an entire year of recreational fishing. Currently, the permit fees for sport or recreational fishing in Polish Marine Areas, which include the Vistula Lagoon, according to the Regional Inspectorate of Marine Fisheries for the following periods are: one week - 30 PLN (approximately 7 euros); one month - 70 PLN (approximately 16 euros); 12 months - 140 PLN (approximately 32 euros). These fees are reduced by $50 \%$ for retirees, those on state disability, children, and youngsters in full-time education up to age 24 , and by $75 \%$ for members of large families. It is possible that the current fees could become a limiting factor, but it must be noted that the fees of recreational fishing permits in the Vistula Lagoon remain attractive in comparison to those for fishing grounds in inland Polish waters (Trella 2012).

Among the other factors that could have piqued interest in the Vistula Lagoon is the flow of information among anglers regarding the excellent catches they make in this fishing ground. Good recreational fishing grounds, such as the Vistula Lagoon, can be promoted by recreational fishers who have fished in them. Similar mechanisms have long operated everywhere else; for example, no article in the press is as effective at promoting English fishing grounds as are rumors spread by anglers at local pubs. This is a phenomenon that O'Grady (1979) observed some forty years ago. In today's information society, the role of the pub has been substituted by the Internet, and through it the flow and reach of information regarding fishing grounds has increased significantly (Martin et al. 2012).

The attractiveness of the lagoon is also impacted by the conviction among Polish anglers that fish stocks in lakes are on the decline, and this is despite the fact that the mean catch per angler fishing in lakes is approximately $49 \mathrm{~kg}$ of fish, which is $25 \%$ higher than the catches made by recreational fishers fishing in the lagoon at a very similar mean number of fishing days per angler (Wołos et al. 2015). Another factor that could indirectly influence interest in the lagoon is the increased fees for inland recreational fishing permits. Decreased sales of recreational fishing permits at lake fisheries enterprises have been noted for years (Trella 2012), and there is clearly increased interest among recreational fishers in marine fishing grounds (Marciniak and Kałuża 2010, Radtke and Dąbrowski 2015), including in the waters of the Vistula Lagoon (Trella 2014, 2015). This situation, which is not desirable for those permitted to operate lake fisheries, is simultaneously an opportunity to develop the region surrounding the lagoon, which could then host the recreational fishers who come to the lagoon.

SWOT analysis identified possible threats to recreational fishing that could stifle the development of angling tourism in this region. Increased fees, which was identified as one such threat, have become a fact, and, currently, the impact of this on the sale of permits is impossible to determine. Among other factors listed as administrative obstacles, such as increased fees for recreational fishing permits, is the requirement for vessel owners and organizers of fishing competitions to report recreational catches. This could deter entrepreneurs from investing in the development of angling tourism. Another factor restricting the development of recreational fisheries in the Vistula Lagoon could be overfishing that is linked with excessive, uncontrolled fishing pressure from anglers. Coleman et al. (2004) conclude that recreational fishing can, within a short period of time, lead to overfishing that can result in substantial ecological and economic problems. Lewin et al. (2006) reached similar conclusions and warn that most problems caused by recreational fisheries stem from the poor management of aquatic basins. As anglers' interest in the lagoon grows, so too will angling pressure, and this could quickly lead to recreational fishing 
affecting commercial fishing (Psuty 2009, 2011, Trella 2014). The conflict between recreational and commercial fishers in the lagoon is not as contentious as that in inland fisheries (Czarkowski and Kupren 2013, Czerwiński 2014, Trapszyc 2015). Despite each side accusing the other of overfishing, the conflict does not lead to such dramatic conflicts as there are over inland waters since most of the profits of commercial fishers operating in the lagoon come from catches of herring, which is not a species that is targeted intensively by anglers. In 2014, commercial catches in the Vistula were 2,927 tons, with herring comprising approximately $81 \%$ of all catches. Despite this, the threat of conflict in the future is real. In the years investigated, total commercial and recreational catches of pikeperch and perch were approximately 217 tons, of this figure approximately 18\% was caught by anglers. This is why recreational fishers who prefer these species could be most likely to come into conflict with commercial fishers. Further, anglers who prefer to catch cyprinids will be less likely to find themselves in conflict with commercial fishers, because in comparison with them, anglers only caught about 5\% of these fish (Szostak et al. 2015). It is noteworthy that Polish anglers exert less fishing pressure on the Vistula Lagoon than do Russian anglers, who also fish the lagoon on their side of the border. Goushchin (2013) estimates in one year approximately 50,000 to 60,000 recreational fishers fished the Curonian Lagoon and the Russian side of the Vistula Lagoon spending there a total of 800,000 days angling and catching approximately 120 to 400 tons of fish.

One of the more serious problems facing Polish commercial and recreational fishers is that of the great cormorant, Phalacrocorax carbo (L.). This bird is a potential threat to fish populations, and not just those in Poland (Švažas et al. 2011, Winkler et al. 2012, Heikinheimo et al. 2016). The Vistula Lagoon is highly significant to the cormorant as it is its most important feeding ground in the early breeding season (Buczma et al. 2011). It is not surprising that Vistula Lagoon fish populations could be threatened by the presence of the great cormorant. The first indications signaling that the cormorants could be having a negative impact on lagoon ichthyofauna came from anglers themselves, who reported that the numbers of ruffe, among other species, were decreasing in angling catches. This species has, for years, dominated the diet of the great cormorant (Bzoma 2011), which means that strong pressure from this piscivore could lead to reduced ruffe populations. SWOT analysis of lake management in the Warmia and Mazury Voivodeship (Czerwiński et al. 2009) indicated that similar problems and similar factors in both analyses include the cormorant issue, angling poaching, administrative problems, and increased anthropogenic pressure.

In Poland, recreational fishing tourism mainly depends on the choice of inland waters (Wołos 2006); however, increasing numbers of recreational fishers are choosing to fish in marine waters (Marciniak and Kałuża 2010, Radtke and Dąbrowski 2015, Trella 2012). It is here that, for several years, there has been the greatest dynamics in the development of recreational fisheries. Many vessel owners have made the decision to shift from commercial fisheries to recreational marine fisheries. According to estimates by Marciniak and Kałuża (2010), revenue from recreational marine fisheries as early as in 2009 reached a level of $50 \%$ of that from commercial fisheries despite the much smaller scale of the catches. Coastal recreational fisheries have great developmental potential, because they provide an opportunity to realize the goals of both lake and marine recreational fisheries. Water and fish are important elements of rural tourism (Czarkowski et al. 2012b, 2014). Agrotourism and other rural tourist enterprises are appearing in the vicinities of lakes, rivers, and lagoons, while fish, in addition to their allure to anglers, are also very important elements of local natural, traditional cuisines.

In the 2011-2014 period, the Vistula Lagoon was a very attractive fishing ground for angling. The analysis of recreational fishing permit sales indicated a strong upward trend, and percentage analysis of the sales distribution and the distribution of fishing days indicated that recreational fishers mainly chose to fish in the spring and summer periods. In terms of tourism, these are the best months that stimulate the development of tourism in this region. Increasing 
numbers of anglers also means that the numbers of tourists visiting the vicinity of the lagoon are also on the rise. Many recreational fishers either come with their families or organize so-called "trips to the water" with friends. Anglers not only fish, but they also book accommodation, eat in local restaurants, and take advantage of other tourist attractions available in the region. When looking at the time anglers spend near the water, it is easy to conclude that they are very desirable customers that are worth making an effort for. Anglers who live far away from the lagoon are also worth bearing in mind, because they more frequently use the tourism infrastructure of the region (hotels, angling shops, restaurants) than do local anglers or those who live nearby. The analysis of how anglers fish provided much information on the topic of recreational fishers who fish the lagoon. Anglers who fish from boats are generally better equipped and can afford their own boats or can afford to rent them. These fishers also use the services of fisheries guides more frequently. They are also more frequent guests of the restaurant and hotels located in the vicinity of the Vistula Lagoon. Similar observations were noted by Ditton et al. (2002), who concluded that anglers who come from farther away to reach a given fishing ground are generally more affluent and equipped with better gear than are local recreational fishers. Additionally, they are not limited by fees for angling permits, because these fees are the smallest expense of the overall cost of a fishing excursion. All of these factors are evidence that there is considerable potential in recreational fishing tourism, which could have a positive impact on the development of the region.

The phenomenon of tourism, including recreational fishing tourism, is recognized widely as a tool for economic development, is discussed in economic categories, and is perceived as a tool for social development (Balińska-Grzelak 2012). Angling tourism has one concretely defined aim - to fish recreationally. It is precisely recreational fishing that is the need the tourist would like to have met. Every angler, just as every tourist, seeks a place with certain attractions that are optimal for him or her. The Vistula Lagoon offers such attractions and many others, too, in addition to fisheries. The behaviors of the recreational fishers themselves shape the local communities of given areas (Balińska-Grzelak 2012). They impact the development of infrastructure and regional development when, to meet their needs, angling shops and equipment rental firms open for business and fisheries guides provide them with services.

The brief analysis of recreational fisheries in the Vistula Lagoon conducted for this paper permits making a preliminary assessment of the impact its development would have on the growth of tourism in this region. Recreational fishing in the Vistula Lagoon potentially provides great opportunities for the development of regional tourism, and further studies of wider scope should be conducted systematically.

Acknowledgments: The authors are grateful to inspectors from DIMF Frombork and DIMF Sztutowo, the staff at the National Marine Fisheries Institute in Gdynia, and the owners of angling shops for their assistance in conducting the research necessary for the paper. The authors extend their special thanks to Andrzej Kapusta for his useful tips and advice.

Author contributions: M.T. designed the study, M.T. conducted the study, M.T. collected data and conducted interviews, M.T. analyzed the data, M.T. wrote the paper, M.T. and M.M. performed the statistical analysis, M.T. M.M performed the SWOT analysis, M.M. corrected the paper.

\section{References}

Arlinghaus R., Cooke S.J. 2009 - Recreational fisheries: socioeconomic importance, conservation issues and management challenges - In: Recreational hunting, conservation and rural livelihoods: science and practice (Eds) B. Dickson, J. Hutton, W.M. Adams, Blackwell Publishing Ltd., Oxford: 39-58.

Balińska-Grzelak A. 2012 - Role of community participation in stimulating the development of tourism - Zeszyty Naukowe Uniwersytetu Szczecińskiego, Ekonomiczne Problemy Turystyki 4(20): 9-18 (in Polish).

Borch T. 2004 - Sustainable management of marine fishing tourism. Some lessons from Norway - Tour. Mar. Environ. 1:49-57. 
Bnińska M., Wołos A. 2001 - Management of selected Polish commercial and recreational lake fisheries activities Fisheries Manag. Ecol. 8: 333-343.

Buczma A., Goc M., Kosmalski W. 2011 - Variation of the Great Cormorant Phalacrocorax carbo sinensis breeding phenology in the biggest European colony in Katy Rybackie (Vistula Spit, N Poland) - Ornis Pol. 52: 231-246. (in Polish)

Bzoma S. 2011 - The great cormorant (Phalacrocorax carbo) conservation program in Poland. Project on strategies for managing the cormorant population in Poland - Szkoła Główna Gospodarstwa Wiejskiego, Warszawa (in Polish).

Cooke S.J., Arlinghaus R., Bartley D. M., Beard T.D., Cowx I.G., Essington T.E., Jensen O.P., Lynch A., Taylor W.W., Watson R. 2014. - Where the waters meet: Sharing ideas and experiences between inland and marine realms to promote sustainable fisheries management - Can. J. Fish. Aquat. Sci. 71: 1593-1601.

Cooke S.J., Cowx I.G. 2006 - Contrasting recreational and commercial fishing: searching for common issues to promote unified conservation of fisheries resources and aquatic environments - Biol. Conserv. 128:93-108.

Coleman F.C., Figueira W.F., Ueland J.S., Crowder L.B. 2004 - The impact of United States recreational fisheries on marine fish populations - Science 305: 1958-1960.

Cholewicka-Goździk K. 2009 - SWOT analysis as a tool for choosing high quality strategies - Problemy Jakości 2: 4-9 (in Polish).

Czarkowski T.K., Kupren K., Kogut B., Śnieg M. 2012a - Recreational fisheries tourism as a significant element of rural tourism - In: Sustainable exploitation of fisheries resources in light of their status in 2011 (Ed.) M. Mickiewicz, Wyd. IRS, Olsztyn: 171-179 (in Polish).

Czarkowski T.K., Kupren K., Turkowski K., Kucharczyk D., Kozłowski K., Mamcarz A. 2012b - Recreational fisheries and fishing grounds in the context of the tourist attractiveness of lakeland regions - Pol. J. Nat. Sci. 27: 453-463.

Czarkowski T.K., Kupren K. 2013 - Recreational vs. commercial fisheries: An unnecessary conflict - Prz. Ryb. 129: 17-23 (in Polish).

Czarkowski T., Kupren K., Kwasiborska D., Jaczewski J. 2014 - Water and fish as significant elements of rural tourism in the Warmia and Mazury Voivodeship Komun. Ryb. 4: 1-8 (in Polish).

Czerwiński T., Wołos A., Mickiewicz M. 2009 - Assessment of weaknesses, strengths, and threats and the potential development of lake management in the Warmia and Mazury Voivodeship - In: The current state and perspectives for development of inland and coastal fisheries in the Warmia and Mazury Voivodeship (Ed.) A. Wołos, Wyd. IRS, Olsztyn: 217-218 (in Polish).
Czerwiński T. 2014 - Comparing commercial and recreational fisheries exploitation of ichthyofauna - In: Principles and conditions for sustainably exploiting fisheries resources - Part II (Eds) M. Mickiewicz, A. Wołos, Wyd. IRS, Olsztyn: 41-52 (in Polish).

Dębicki W. 2003 - Fish in the Lagoon - Wędkarz Polski 8: 56-61 (in Polish).

Ditton R.B., Holland S.M., Anderson D.K. 2002 - Fishing as tourism - Fisheries 27:17-23

Goushchin A.V. 2013 - Fishery in the Russian part of the Vistula lagoon - Atlantic Branch of P.P. Shirshov Institute of Oceanology of Russian Academy of Science: 40 p.

Heikinheimo O., Rusanen P., Korhonen K. 2016 - Estimating the mortality caused by great cormorant predation on fish stocks: pikeperch in the Archipelago Sea, northern Baltic Sea, as an example - Can. J. Fish. Aquat. Sci. 73: 84-93.

Joyeux J.C., Ward A.B. 1998 - Constraints on coastal lagoon fisheries - Adv. Mar. Biol. 34: 73-199.

Kruk M. 2011 - Vistula Lagoon - between land and sea. Problematic consequences - In: The Vistula Lagoon: The natural environment and new study methods based on the example of the VISLA project (Eds) M. Kruk, A. Rychter, M. Mróz, Wyd. PWSZ, Elbląg: 21-50 (in Polish).

Kurleto M. 2013 - Sustainable management of lakes taking into consideration the tourism and nature conservation in Australia and New Zealand - Pol. J. Nat. Sci. 28: 91-106.

Lewin W.C., Arlinghaus R., Mehner T. 2006 - Documented and potential biological impacts of recreational fishing: Insights for management and conservation - Rev. Fish. Sci. 14: 305-367.

Marciniak M., Kałuża H. 2010 - The maritime angling as a stimulator of development of the tourism sector in seaside regions - Folia Pomer. Univ. Technol. Stetin., Oeconomica 284 (61): 61-68 (in Polish).

Martin D.R., Pracheil B.M., DeBoer J.A., Wilde G.R., Pope K.L. 2012 - Using the Internet to understand angler behavior in the information age - Fisheries 37: 458-463.

Mickiewicz M. 2013 - Economic effectiveness of stocking lakes in Poland - Arch. Pol. Fish. 21: 323-329.

Miotk-Szpiganowicz G., Zachowicz J., Uścinowicz S. 2007 A new look at the development of southern Baltic coastal aquatic basins - Stud. Lim. Tel. 1: 127-136 (in Polish).

Moksness E., Gjøsæter J., Lagaillarde G., Mikkelsen E., Moland Olsen E., Sandersen H.T., Helge Vølstad J. 2011 - Effects of fishing tourism in a coastal municipality: a case study from Risør, Norway - Ecol. Soc. 16: 11.

Montano O.J.F., Dibble E.D., Jackson D.C., Rundle K.R. 2005 - Angling assessment of the fisheries of Humacao Natural Reserve lagoon system, Puerto Rico - Fish. Res. 76: 81-90.

O'Grady K.T. 1979 - The use of angler-obtained information in the management of put-and-take trout fisheries - In: Proc. $1^{\text {st }}$ Brit. Fresh. Fish. Conf., University of Liverpool: 272-284. 
Psuty I. 2009 - Fisheries in the Vistula Lagoon - In: Assessing the current status and perspectives for the development of inland fisheries and coastal fisheries areas in the Warmia and Mazury Voivodeship (Ed.) A. Wołos, Wyd. IRS, Olsztyn: 271-304 (in Polish).

Psuty I. 2011 - Vistula Lagoon - In: Fisheries development strategies in the Warmia and Mazury Voivodeship until 2030 (Ed.) A. Wołos, M. Mickiewicz, Wyd. IRS, Olsztyn: 42-50 (in Polish).

Psuty-Lipska I., Borowski W. 2003 - Factors affecting fish assemblages in the Vistula Lagoon - Arch. Fish. Marine Res. 50: 253-270.

Radtke K., Dąbrowski H. 2015 - New legislation on marine fisheries and its implications for recreational fisheries Wiad. Ryb. 7-8: 9-12 (in Polish).

Švažas S., Chukalova N., Grishanov G., Pūtys Ž., Sruoga A., Butkauskas D., Raudonikis L., Prakas P. 2011 - The role of Great cormorant (Phalacrocorax carbo sinensis) for fish stock and dispersal of helminths parasites in the Curonian Lagoon Area - Vet. Med. Zoot. 55:79-85

Szczerbowski J. 1998 - Encyclopedia of Fisheries and Angling - Wyd. IRS, Olsztyn, 476 p. (in Polish).

Szostak S., Rakowski M., Budny T. 2015 - Marine Fisheries Sector in 2014 r. - Wyd. MIR-PIB, Gdynia: 28 p. (in Polish).

Trapszyc A. 2015 - Fisher and angler, us and them - eternal opposition or passing stereotype? Reflections of a cultural anthropologist - In: Sustainable exploitation of fisheries resources in light of their status in 2011 (Eds) M. Mickiewicz, A. Wołos, Wyd. IRS, Olsztyn: 111-123 (in Polish).

Trella M. 2012 - Trends in the sale of angling permits for lake fisheries in 1998-2011 - In: Sustainable exploitation of fisheries resources in light of their status in 2011 (Ed.) M. Mickiewicz, Wyd. IRS, Olsztyn: 65-75 (in Polish).
Trella M. 2013 - Comprehensive studies of recreational fisheries pressure and catches in the Vistula Lagoon Komun. Ryb. 6: 34 (in Polish).

Trella M. 2014 - Pressure and angling catches in the Vistula Lagoon in 2011 - Komun. Ryb. 1: 5-9 (in Polish).

Trella M. 2015 - Characteristics of recreational fishing pressure and catches in the Vistula Lagoon in 2012 - Komun. Ryb. 6: 1-6 (in Polish).

Veiga P., Ribeiro J., Gonçalves J.M.S., Erzini K. 2010 - Quantifying recreational shore angling catch and harvest in the south of Portugal (Northeast Atlantic): implications for conservation and integrated fisheries management - J. Fish Biol. 76: 2216-2237.

Winkler H.M., Starck C., Myts D. 2012 - Cormorant food and the possible impact on indigenous fish species in the Pomeranian Bay off the coast of Germany - In: The Cormorant in sustainable exploitation of fisheries resources, MIR-PIB Gdynia: 4-8 (in Polish).

Wołos A. 1992 - Developing research methods and their application in determining guidelines for managing lakes for recreational fisheries - Doctoral dissertation, IRS Olsztyn: 62 p (in Polish).

Wołos A. 1994 - Recreational fishing as an element of lake exploitation - In: Current problems of lake fisheries (Ed.) A. Wołos, Wyd. IRS, Olsztyn: 119-132 (in Polish).

Wołos A. 2006 - Social, economic, and ecological significance of recreational fisheries - In: Fisheries, recreational fishing, eco-development (Ed.) A. Wołos, Wyd. IRS, Olsztyn: 57-71 (in Polish).

Wołos A. 2000 - Economic significance of recreational fisheries in enterprises entitled to exploit lake fisheries - Arch. Pol. Fish. 8 (Suppl. 1): 54 (in Polish).

Wołos A., Draszkiewicz-Mioduszewska H., Trella M. 2015 Description of recreational fisheries pressure and catches in lakes exploited by the fisheries sector - In: Sustainable exploitation of fisheries resources in light of their status in 2014 (Eds) M. Mickiewicz, A. Wołos, Wyd. IRS, Olsztyn: 159-171 (in Polish). 